\title{
ANALISIS FAKTOR-FAKTOR YANG MEMPENGARUHI AUDIT DELAY PADA PERUSAHAAN MANUFAKTUR SUBSEKTOR MINYAK DAN GAS BUMI YANG TERDAFTAR DI BURSA EFEK INDONESIA PERIODE 2016-2020
}

\author{
Sri Hartini, SE,M.Si \\ Universitas Amir Hamzah \\ Srihartini393@gmail.com
}

\begin{abstract}
Abstrak
Perusahaan yang menerima unqualified opinion dianggap sebagai goodnews (kabar baik) sehingga penyampaian laporan keuangannya lebih cepat.Sebaliknya yang menerima selain unqualified opinion dianggap sebagai bad news (berita buruk), maka perusahaan akan menyampaikan laporan keuangannya ke publik lebih lama karena banyak yang perlu diteliti supaya laporan keuangannya tidak salah saji sehingga. Jika perusahaan menerima unqualified opinion maka audit delay akan semakin pendek dibandingkan perusahaan menerima selain unqualified opinion.Laba menunjukkan good news sehingga perusahaan ingin lebih cepat mengumumkan good news tersebut dan sebaliknya jika perusahaan mengalami kerugian maka pihak manajemen ingin menunda bad news tersebut. Perusahaan yang melaporkan kerugian mungkin akan meminta auditor untuk mengatur waktu auditnya lebih lama dibandingkan biasanya karena hal ini merupakan bad news. Sebaliknya jika perusahaan melaporkan laba yang tinggi maka perusahaan berusaha laporan keuangan auditan di publikasikan secepatnya sehingga goodnews tersebut cepat diketahui oleh para investor dan pihak yang berkepentingan lainnya. Jika perusahaan mengalami laba maka audit delay akan semakin pendek dibandingkan perusahaan yang mengalami kerugian.
\end{abstract}

Keyword : Audit Delay, Perusahaan Manufaktur, Bursa Efek Indonesia, Periode 2016-2020 


\section{PENDAHULUAN}

Perusahaan yang memiliki tingkat profitabilitas yang tinggi membutuhkan waktu dalam pengauditan laporan keuangan lebih cepat dikarenakan harus menyampaikan kabar baik tersebut kepada publik atau pemegang saham. Jika perusahaan mengalami profitabilitas yang lebih tinggi maka audit delay akan semakin pendek dibandingkan perusahaan yang tingkat profitabilitasnya lebih rendah. Terdapat banyak faktor yang mempengaruhi audit delay, seperti ukuran perusahaan, jenis opini auditor, laba atau rugi perusahaan, tingkat profitabilitas, tingkat solvabilitas, kualitas auditor, jumlah komite audit, kompleksitas operasi perusahaan, pos-pos luar biasa, reputasi auditor dan konvergensi IFRS. Namun pada penelitian ini peneliti mengambil empat faktor yang akan diuji yaitu ukuran perusahaan, jenis opini auditor, laba atau rugi perusahaan dan profitabilitas. Meskipun penelitian telah banyak dilakukan mengenai audit delay pada perusahaan yang terdaftar di Bursa Efek Indonesia namun hasil penelitian tersebut beragam, hal ini disebabkan karena perbedaan sifat variabel independen dan variabel dependen yang diteliti, perbedaan periode pengamatan serta perbedaan dalam metodologi statistik yang digunakan. Ukuran perusahaan mencerminkan besarnya lingkup atau luas perusahaan dalam menjalankan operasinya. Perusahaan berskala besar biasanya menyelesaikan laporan keuangannya lebih cepat daripada perusahaan berskala kecil. Manajemen perusahaan besar memiliki insentif untuk mengurangi audit delay karena perusahaan berskala besar dipantau lebih ketat oleh para investor dan regulator, dan dengan demikian mendapat tekanan besar dari pihak eksternal untuk melaporkan laporan keuangannya lebih cepat.

\section{KAJIAN PUSTAKA}

Ukuran perusahaan adalah besar kecilnya perusahaan dilihat dari besarnya nilai equity, nilai penjualan atau nilai aktiva yang diukur dengan rumus SIZE = $\log N$ (total aset).

Jenis Opini Auditor adalah laporan yang dibuat oleh pemeriksa (auditor) setelah memeriksa penemuan-penemuan yang berkenaan dengan laporan keuangan suatu perusahaan yang diukur dengan perusahaan yang menerima pendapat unqualified opinion diberi skor 1 dan perusahaan yang menerima pendapat selain unqualified opinion diberi skor 0.

Laba atau Rugi Perusahaan adalah suatu laporan yang menunjukkan pendapatan-pendapatan dan biaya-biaya dari suatu unit usaha untuk suatu periode tertentu. Selisih antara pendapatan-pendapatan dan biaya merupakan laba yang diperoleh atau rugi yang diderita perusahaan yang diukur dengan Perusahaan yang mengalami laba diberi skor 1 dan perusahaan yang mengalami rugi diberi skor 0 .

Profitabilitas adalah Ringkasan hasil bersih aktivitas operasi usaha dalam periode tertentu yang dinyatakan dalam istilah keuangan yang diukur dengan Profitabilitas (ROA) :Pofit before tax / total assets.

Jurnal Insitusi Politeknik Ganesha Medan

Juripol, Volume 4 Nomor 2 September 2021 
Audit Delay adalah Lamanya hari yang dibutuhkan auditor untuk menyelesaikan pekerjaan auditnya, yang diukur dari tanggal penutupan tahun buku hingga tanggal diterbitkannya laporan keuangan audit yang diukur dengan Audit Delay $=$ tanggal terbit laporan keuangan - tanggal tutup tahun buku .

\section{METODE PENELITIAN}

\section{Lokasi Penelitian}

Lokasi penelitian ini adalah perusahaan minyak dan gas bumi yang terdaftar di Bursa Efek Indonesia yang diakses melalui situs resmi Bursa Efek Indonesia, yaitu www.idx.co.id.

\section{Populasi dan Sampel}

Menurut Sugiyono (2012:90) populasi adalah wilayah generalisasi yang terdiri atas objek atau subjek yang mempunyai kualitas dan karakteristik tertentu yang ditetapkan oleh peneliti untuk dipelajari dan kemudian ditarik kesimpulannya. Populasi dalam penelitian ini adalah laporan keuangan akhir tahun dari perusahaan Minyak dan Gas Bumi yang terdaftar di Bursa Efek Indonesia pada tahun 2015-2020. Sebanyak 8 perusahaan Minyak dan Gas Bumi yang terdaftar di Bursa Efek Indonesia pada periode 2015 - 2020 dan jumlah tersebut merupakan jumlah populasi peneliti.

Sampel adalah bagian dari jumlah dan karakteristik yang dimiliki oleh populasi tersebut, sebagaimana dikemukakan oleh Sugiyono (2012:91). Teknik pengumpulan sampel yang digunakan adalah Purposive Sampling, yang merupakan teknik penentuan sampel anggota populasi dengan pertimbangan atau kriteria tertentu, Sugiyono (2012:122).

Kriteria (pertimbangan) pengambilan sampel yang digunakan oleh peneliti adalah sebagai berikut :

1. Perusahaan minyak dan gas bumi yang terdaftar di Bursa Efek Indonesia selama periode penelitian, yaitu 2015 - 2020.

2. Perusahaan yang menerbitkan dan mempublikasikan laporan keuangan selama periode pengamatan.

3. Laporan keuangan 2015 - 2020 perusahaan tersebut telah diaudit oleh auditor independen.

Berdasarkan kriteria yang disebutkan di atas, maka perusahaan yang menjadi sampel dalam penelitian sebanyak 6 (enam) perusahaan minyak dan gas bumi yang terdaftar di Bursa Efek Indonesia selama 5 (lima) periode, yaitu periode 2015-2020 dengan total 30 sampel.

\section{Analisis Linier Berganda}

Model ini digunakan dalam penelitian ini.Dimana alat analisis yang dipergunakan adalah analisis regresi linier berganda yang bertujuan untuk menguji pengaruh luar dua atau lebih varibel independen terhadap variabel 
dependen. Persamaan regresi berganda dalam model penelitian ini adalah sebagai berikut :

$\mathrm{Y}=\mathrm{a}+\mathrm{b} 1 \mathrm{X} 1+\mathrm{b} 2 \mathrm{X} 2+\mathrm{b} 3 \mathrm{X} 3+\mathrm{b} 4 \mathrm{X} 4+\mathrm{e}$

\section{DISCUSSION}

\section{Pengujian Asumsi Klasik}

\section{Hasil Uji Normalitas}

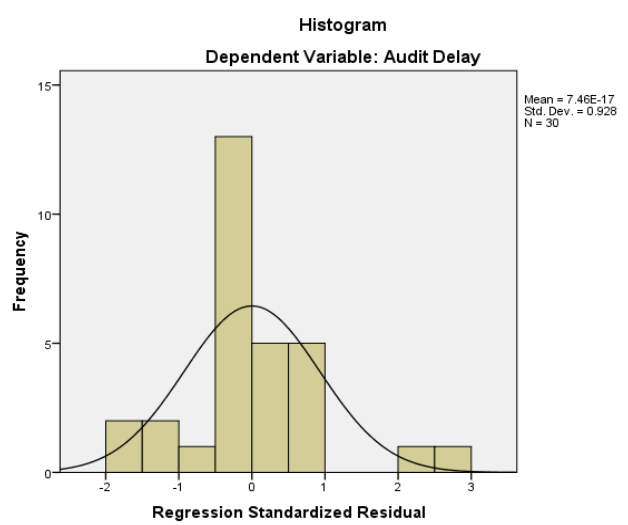

Sumber : data diolah, 2021 (hasil output SPSS)

Berdasarkan Gambar diatas, maka dapat dijelaskan bahwa data membentuk garis kurva cenderung simetri terhadap mean (U). Hasil pengujian ini menunjukkan data berdistribusi normal.

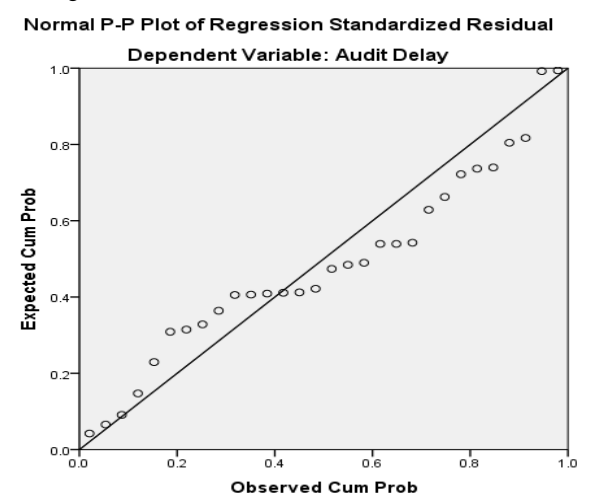

Sumber : data diolah, 2021 (hasil output SPSS)

Berdasarkan Gambar diatas, maka dapat dijelaskan bahwa data menyebar mengikuti garis diagonal. Hasil pengujian ini menunjukkan bahwa data berdistribusi normal. 


\begin{tabular}{llr}
\multicolumn{2}{c}{ One-Sample Kolmogorov-Smirnov Test } \\
\hline & \multicolumn{2}{c}{$\begin{array}{c}\text { Unstandardized } \\
\text { Residual }\end{array}$} \\
\hline $\mathrm{N}$ & & 30 \\
Normal Parameters ${ }^{\mathrm{a}, \mathrm{b}}$ & Mean \\
& Std. & .0000000 \\
& Deviation & 21.47679101 \\
Most Extreme & Absolute & .154 \\
Differences & Positive & .154 \\
& Negative & -.129 \\
Kolmogorov-SmirnovZ & .154 \\
Asymp. Sig. (2-tailed) & & $.066^{c}$ \\
\hline a. Test distribution is Normal. & \\
b. Calculatedfrom data. \\
c. Lilliefors Significance Correction.
\end{tabular}

Sumber : data diolah, 2021 (hasil output SPSS)

Berdasarkan Tabel diatas, maka dapat diketahui nilai kolmogorov-smirnov sebesar 0.154 dengan nilai signifikan lebih besar dari 0.05 , yaitu sebesar 0.066 . Hasil pengujian ini menunjukkan bahwa data berdistribusi normal.

\section{Hasil Uji Heteroskedastisitas}

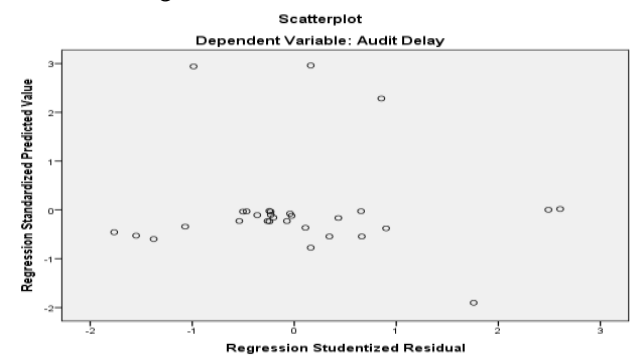

Sumber : data diolah, 2021 (hasil output SPSS)

Berdasarkan Gambar diatas, maka dapat dijelaskan bahwa titik-titik hasil pengolahan data menyebar di bawah sumbu Y dan tidak mempunyai pola yang teratur. Hasil pengujian ini menunjukkan bahwa tidak terjadi heteroskedastisitas atau terjadi homokedastisitas.

\section{Hasil Uji Autokorelasi}

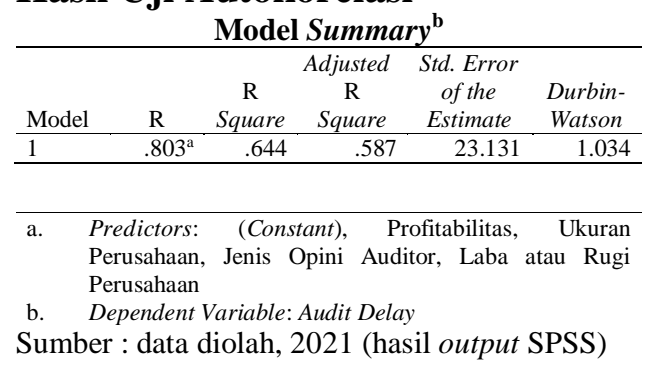

Berdasarkan Tabel diatas, maka dapat diketahui nilai Durbin-Watson (d) adalah sebesar 1.034. Nilai tersebut akan dibandingkan dengan nilai tabel DurbinWatson yang menggunakan signifikansi 5\% (Tabel Durbin-Watson dapat dilihat pada lampiran VIII) untuk jumlah sampel (n) sebanyak 30 dan jumlah variabel independen (k) sebanyak 4. Berdasarkan tabel Durbin-Watson, dapat diketahui 
nilai dL sebesar 1.1426 dan nilai dU sebesar 1.7386. Oleh karena itu, nilai d, dL, $\mathrm{dU}$ tersebut memenuhi kriteria ke-I dengan syarat $0<\mathrm{d}<\mathrm{dL}$, yaitu dengan nilai 0 $<1.034<1.1426$. Hasil pengujian ini menunjukkan bahwa tidak ada autokorelasi positif.

\section{Hasil Uji Multikolinieritas}

\begin{tabular}{|c|c|c|c|}
\hline \multicolumn{4}{|c|}{ Coefficients $^{\mathrm{a}}$} \\
\hline \multirow[b]{2}{*}{ Model } & & \multicolumn{2}{|c|}{ Collinearity Statistics } \\
\hline & & Tolerance & VIF \\
\hline \multirow[t]{5}{*}{1} & (Constant) & & \\
\hline & Ukuran Perusahaan & .794 & 1.260 \\
\hline & Jenis Opini Auditor & .589 & 1.696 \\
\hline & $\begin{array}{l}\text { Laba atau Rugi } \\
\text { Perusahaan }\end{array}$ & .484 & 2.067 \\
\hline & Profitabilitas & .704 & 1.420 \\
\hline
\end{tabular}

Berdasarkan tabel diatas, maka dapat diketahui bahwa :

1. Nilai tolerancevalue untuk variabel ukuran perusahaan, jenis opini auditor, laba atau rugi perusahaan dan profitabilitas memiliki nilai lebih besar dari 0.1 , yaitu sebesar 0.794 untuk ukuran perusahaan, jenis opini auditor sebesar 0.589 , sebesar 0.484 untuk laba atau rugi perusahaan dan sebesar 0.704 untuk profitabilitas.

2. Nilai variance inflation factor (VIF) untuk variabel jenis opini auditor, laba atau rugi perusahaan dan profitabilitas memiliki nilai lebih kecil dari 10, yaitu sebesar 1.260 untuk ukuran perusahaan, sebesar 1.696 untuk jenis opini auditor, sebesar 2.067 untuk laba atau rugi perusahaan dan sebesar 1.420 untuk profitabilitas.

Hasil pengujian diatas menunjukkan bahwa variabel independen (ukuran perusahaan, jenis opini auditor, laba atau rugi perusahaan dan profitabilitas) tidak mengalami multikolinieritas.

\section{Hasil Analisis Regresi Linier Berganda}

\begin{tabular}{|c|c|c|c|c|c|c|}
\hline \multicolumn{7}{|c|}{ Coefficients $^{2}$} \\
\hline & & \multicolumn{2}{|c|}{$\begin{array}{c}\text { Unstandardized } \\
\text { Coefficients }\end{array}$} & \multirow{2}{*}{$\begin{array}{c}\text { Standardized } \\
\text { Coefficients } \\
\text { Beta }\end{array}$} & \multirow[b]{2}{*}{$\mathrm{T}$} & \multirow[b]{2}{*}{ Sig. } \\
\hline \multicolumn{2}{|l|}{ Model } & B & Std. Error & & & \\
\hline \multirow[t]{5}{*}{1} & (Constant) & 235.606 & 117.013 & & 2.014 & .055 \\
\hline & Ukuran Perusahaan & -2.688 & 3.757 & -.096 & -.716 & .481 \\
\hline & Jenis Opini Auditor & 92.791 & 18.335 & .786 & 5.061 & .000 \\
\hline & Laba atau Rugi Perusahaan & 27.319 & 20.238 & .231 & 1.350 & .189 \\
\hline & Profitabilitas & 173.746 & 72.198 & .342 & 2.407 & .024 \\
\hline
\end{tabular}

Sumber : data diolah, 2021 (hasil output SPSS)

Berdasarkan tabel diatas, maka dapat diketahui persamaan regresi linier berganda dalam penelitian ini adalah :

Audit Delay $=$ 235.606 - 2.688 Size +92.791 Jenis Opini Auditor + 27.319

Laba atau Rugi Perusahaan+173.746 Return on Assets + e

Hasil Uji Koefisien Determinasi (Uji $\mathbf{R}^{2}$ ) Model Summary ${ }^{\mathrm{b}}$

Jurnal Insitusi Politeknik Ganesha Medan 


\begin{tabular}{|c|c|c|c|c|}
\hline Model & $\mathrm{R}$ & $\begin{array}{cc} & \text { Adjusted } \\
\mathrm{R} & \mathrm{R} \\
\text { Square } & \text { Square } \\
\end{array}$ & $\begin{array}{c}\text { Std. } \\
\text { Error of } \\
\text { the } \\
\text { Estimate }\end{array}$ & $\begin{array}{l}\text { Durbin- } \\
\text { Watson }\end{array}$ \\
\hline 1 & $.803^{\mathrm{a}}$ & $\begin{array}{ll}.644 & .587 \\
\end{array}$ & 23.131 & 1.034 \\
\hline a. & $\begin{array}{l}\text { Predictors: } \\
\text { Perusahaan, } \\
\text { Perusahaan }\end{array}$ & $\begin{array}{c}\text { (Constant }), \quad P_{1} \\
\text { Jenis Opini Aud }\end{array}$ & $\begin{array}{l}\text { ofitabilitas, } \\
\text { tor, Laba }\end{array}$ & $\begin{array}{r}\text { Ukuran } \\
\text { atau Rugi }\end{array}$ \\
\hline $\begin{array}{l}\text { b. } \\
\text { Sumb }\end{array}$ & $\begin{array}{l}\text { Dependent } \\
\text { per : data }\end{array}$ & $\begin{array}{l}\text { Variable: Audit Dela } \\
\text { diolah, } 2021 \text { (ha }\end{array}$ & il output & SPSS) \\
\hline
\end{tabular}

Berdasarkan Tabel diatas, maka dapat diketahui nilai Adjusted $\mathrm{R}$ square adalah sebesar 0.587 atau $58.7 \%$. Hal ini berarti sebesar $58.7 \%$ variabel Audit Delay dapat dijelaskan oleh variabel ukuran perusahaan, jenis opini auditor, laba atau rugi perusahaan dan profitabilitas, sedangkan sisanya sebesar $41.3 \%$ variabel Audit Delay dapat dijelaskan oleh variabel lain yang tidak diteliti dalam penelitian ini.

\section{KESIMPULAN}

Berdasarkan hasil analisis dan pembahasan yang telah diuraikan, maka kesimpulan dalam penelitian ini adalah :

1. $\quad$ Model regresi pada penelitian ini adalah Audit Delay $=\mathbf{2 3 5 . 6 0 6}-\mathbf{2 . 6 8 8}$ Size + 92.791 Jenis Opini Auditor + 27.319 Laba atau Rugi Perusahaan + 173.746 Return on Assets + e.

2. Secara parsial, variabel ukuran perusahaan tidak berpengaruh signifikan terhadap Audit Delay pada perusahaan minyak dan gas bumi yang terdaftar di Bursa Efek Indonesia untuk periode 2015-2020.

3. Secara parsial, variabel jenis opini auditor berpengaruh signifikan terhadap Audit Delay pada perusahaan minyak dan gas bumi yang terdaftar di Bursa Efek Indonesia untuk periode 2015-2020.

4. Secara parsial, variabel laba atau rugi perusahaan tidak berpengaruh signifikan terhadap Audit Delay pada perusahaan minyak dan gas bumi yang terdaftar di Bursa Efek Indonesia untuk periode 2015-2020.

5. Secara parsial, variabel profitabilitas / Return on Assets berpengaruh signifikan terhadap Audit Delay pada perusahaan minyak dan gas bumi yang terdaftar di Bursa Efek Indonesia untuk periode 2015-2020.

6. Secara simultan, variabel ukuran perusahaan, jenis opini auditor, laba atau rugi perusahaan dan profitabilitas / Return on Assets berpengaruh signifikan terhadap Audit Delay pada perusahaan minyak dan gas bumi yang terdaftar di Bursa Efek Indonesia untuk periode 2015-2020.

7. Besarnya pengaruh yang diberikan oleh variabel ukuran perusahaan, jenis opini auditor, laba atau rugi perusahaan dan profitabilitas terhadap Audit Delay pada perusahaan minyak dan gas bumi yang terdaftar di Bursa Efek Indonesia periode $2015-2020$ adalah sebesar $58.7 \%$ dan sisanya $41.3 \%$ dipengaruhi oleh variabel lain yang tidak diteliti dalam penelitian ini 
(sesuai dengan nilai Adjusted R Square yang diperoleh dari hasil penelitian ini).

\section{REFERENCES}

Abdillah. Gabriel. 2015. Analisis Faktor-Faktor yang Mempengaruhi Lamanya Penyelesaian Audit (Audit Delay) pada Perusahaan Manufaktur yang Terdapat di Bursa Efek Indonesia (BEI) Tahun 2011-2013. UniversitasSumatera Utara, Medan

Apriliane, Malinda Dwi. 2015. Analisis Faktor-Faktor yang Mempengaruhi Audit Delay (Studi Empiris pada Perusahaan Pertambangan yang Terdaftar di Bursa Efek Indonesia Tahun 2008-2012). Universitas Negeri Yogyakarta, Yogyakarta

Mauliddya. Amy. 2016. Analisis Faktor-Faktor yang Mempengaruhi Audit Delay (Studi Empiris pada Pemerintah Kabupaten/Kota di Indonesia). Universitas Sumatera Utara, Medan

Natalia. Corry. 2015. Anilisis Faktor-Faktor Yang Mempengaruhi Audit Delay Pada Perusahaan Food and Beverage yang Terdaftar di BEI. UniversitasSumatera Utara, Medan

Ghozali.Imam.2011. Aplikasi Analisis Multivariate dengan Program SPSS.Semarang :Badan Penerbit Universitas Diponegoro

Sibarani. Yolla Angela Rulianty. 2013. Analisis Faktor-Faktor yang Mempengaruhi Audit Delay Pada Perusahaan Minyak dan Gas Bumi yang Terdaftar di Bursa Efek Indonesia (BEI). Universitas Sumatera Utara, Medan

Sunyoto, Danang. 2013. Metodologi Penelitian Akuntansi. Bandung : PT. Refika Aditama

Www.junaidichaniago.wordpress.com

www.idx.co.id

Jurnal Insitusi Politeknik Ganesha Medan

Juripol, Volume 4 Nomor 2 September 2021 